\title{
Cladodes applied as decentralized ecotechnology to improve water quality and health in remote communities that lack sanitation
}

\author{
William Michelon ${ }^{1} \cdot$ Paulo Reis Junior ${ }^{1}$. Priscila M. Knoblauch ${ }^{1}$. Gilmar A. da Rosa ${ }^{1}$. Apolline P. Mass ${ }^{2}$. \\ Luciane Verona $^{2} \cdot$ Maicon A. Reimers $^{2} \cdot$ Franciele Engel $^{2} \cdot$ Gislaine Fongaro $^{3} \cdot$ Aline Viancelli $^{1}$
}

Received: 6 September 2019 / Accepted: 17 December 2019 / Published online: 2 January 2020

(c) Springer Nature Switzerland AG 2020

\begin{abstract}
Access to treated water has increased in urban areas of the developing world in recent decades: However, many regions still lack proper sanitation or safe drinking water. Among the existing studies on low-cost water treatment methods to solve this problem, the application of cacti species is still a recent one. Considering this, the present study aimed to evaluate the best cactus species (Opuntia ficus-indica, Cereus jamacaru and Cereus jamacaru monstrosus) on the simultaneous removal of pathogens, improvement in physical-chemical conditions, without letting cytotoxic residues on water. Tests were carried out using river water and small pieces of cladodes at dosages of $15,25,50$ and $75\left(\mathrm{~g} \mathrm{~L}^{-1}\right)$ in agitation periods of $2 \mathrm{~min}$ at $60 \mathrm{rpm}$ and settling periods of 30,120 and $360 \mathrm{~min}$. O. ficus-indica performed better than C. jamacaru in removing E. coli, turbidity, color, iron and nitrate, and a dosage of $25 \mathrm{~g} \mathrm{~L}^{-1}$ of cactus was found to be the most efficient for water treatment. This dosage resulted in a maximum non-cytotoxic exposition time of $30 \mathrm{~min}$ for O. ficus-indica and of $120 \mathrm{~min}$ for C. jamacaru. Considering how efficient these cacti have shown to be in removing pollutants, and how widespread and easy to cultivate they are, they could be considered as a safe, low-cost alternative to other coagulation-flocculation products in water treatment processes.
\end{abstract}

Keywords Waterborne · Bacteria removal $\cdot$ Metal settling · Opuntia ficus-indica $\cdot$ Cereus jamacaru $\cdot$ Cereus jamacaru monstrosus

\section{Introduction}

Access to treated water has increased in urban areas of the developing world in recent decades; however, many regions still lack proper sanitation or access to piped water. As a consequence, there is an increased occurrence of waterborne diseases $[16,20]$.

The occurrence of waterborne diseases is sometimes linked to low sanitation coverage. This lack of proper sanitation may lead to epidemic cases of typhoid fever, gastroenteritis, diarrhea, hepatitis, conjunctivitis and other clinical manifestations caused by viruses, protozoa, helminths and bacteria, affecting especially developing countries [5, 10].

Therefore, there is an increasing concern in providing clean and safe drinking water supplies all around the world, despite the existence of various water treatment strategies [29]. Several traditional and advanced technologies, such as coagulation/flocculation, flotation, precipitation, adsorption, membrane filtration and biological and electrolytic methods, have been utilized to remove particulates and other contaminants from water $[18,19]$. Nonetheless, these technologies are disadvantageous due to the generation of toxic sludge, limitations in the removal of pollutants, process

$\triangle$ William Michelon, william@unc.br| ${ }^{1}$ Programa de Mestrado em Engenharia Civil, Sanitária e Ambiental - Universidade do Contestado, Victor Sopelsa, 3000, Concórdia, SC 89711-330, Brazil. ${ }^{2}$ Universidade do Contestado, Concórdia, SC, Brazil. ${ }^{3}$ Universidade Federal de Santa Catarina, Florianópolis, SC, Brazil. 
complexity, high consumption of chemicals, and high costs of maintenance and operation [15]. Additionally, the fact that constructing a water plant is not always a viable solution, especially in remote communities, makes the need to find decentralized alternatives a priority in such cases.

Coagulation-flocculation process is a widely used treatment on water or wastewater clarification due to its simplicity and effectiveness. The importance of the coagulation process is based on the formation of microflocs, which help to remove turbidity, pathogens and other dispersed colloids [11]. This process is usually performed through the use of inorganic salts, such as aluminum [21]. However, residual aluminum in drinking water has been related to health problems such as Alzheimer's disease in humans and toxicity to aquatic life $[7,17]$. Moreover, increased awareness of costs and environmental health problems related to the use of conventional coagulants (aluminum and iron) has steered study interests toward natural organic coagulants [24].

Natural coagulants are predominantly plant-based. More than 14 species with a wide range of ecological distribution have already been described as successful to water treatment [11], which makes them a viable, low-cost, multifunctional and biodegradable alternative $[22,37]$.

Application of cacti species for water treatment is fairly recent when compared to other natural coagulants such as okra (Hibiscus esculentus) [14], chitosan [31], beans (Phaseolus spp.) [3], peach kernel (Prunus persica sieb. zucc.) [21], nirmali plants (Strychnos potatorum) [6] and Moringa oleifera [28]. Additionally, as most studies conducted so far have only considered the application of cacti either alone or with aluminum sulfate for removing turbidity [37, 1], little is known about the effectiveness of these coagulants on removing pathogens and water toxicity.

This study evaluated the application of cacti species Opuntia ficus-indica, Cereus jamacaru and Cereus jamacaru monstrosus as an alternative ecotechnology for water treatment, considering the removal of pathogens, improvement in physical-chemical conditions and cytotoxicity evaluation of treated water. Although the most commonly studied cactus species for water treatment is Opuntia ficus-indica [39], and Cereus jamacaru and Cereus jamacaru monstrosus are not commonly mentioned in the literature, they were included in this study because they are commonly found in southern Brazil.

\section{Materials and methods}

\subsection{Acquisition of water samples and cactus specimen}

Water samples were collected from the Queimados River $\left(27^{\circ} 13^{\prime} 53.7^{\prime \prime} \mathrm{S} 52^{\circ} 1^{\prime} 28.4^{\prime \prime} \mathrm{W}\right)$ in the city of Concórdia,
Santa Catarina, Brazil, and characterized according to the Standard Methods For The Examination of Water and Wastewater by the American Public Health Association [4]. The river is polluted with human and animal wastewater. Cladodes from three cacti species, Opuntia ficus-indica, Cereus jamacaru and Cereus jamacaru monstrosus, were collected from cultivation areas in Concórdia, morphologically identified, washed with tap water to remove impurities and then cut into small pieces of about $1 \mathrm{~cm}^{3}$.

\subsection{Experimental setup}

\subsubsection{Bio-coagulation tests}

Bio-coagulation tests were carried out with $1 \mathrm{~L}$ of river water through a jar test at room temperature $\left( \pm 25^{\circ} \mathrm{C}\right)$. Cactus in natura was used as bio-coagulant and added in dosages of $15,25,50$ and $75\left(\mathrm{~g} \mathrm{~L}^{-1}\right)$ [2]. The mixture was subjected to agitation for $2 \mathrm{~min}$ at $60 \mathrm{rpm}$. During settling, samples were collected from $2.5 \mathrm{~cm}$ depth at 30-, 120- and 360-min intervals. Samples were collected for physicochemical, microbial and cytotoxicity assay.

\subsubsection{Determination of physicochemical characteristics}

The quantification of turbidity (uT), color (uH), iron, sulfate, nitrite, nitrate and ammonia $\left(\mathrm{mg} \mathrm{L}^{-1}\right)$ was performed according to APHA standards [4].

\subsubsection{Microbiological assay}

For bacteria removal tests, water samples were artificially inoculated with Escherichia coli (E. coli) and Salmonella enterica serovar Typhimurium (S. typhimurium) at concentrations equivalent to a 0.5 tube in the McFarland scale (Remel ${ }^{\circ}$ ). Quantification of E. coli and S. typhimurium was performed by collecting $1 \mathrm{~mL}$ from the supernatant and $1 \mathrm{~mL}$ from the precipitated fractions, which were serially diluted on a logarithmic basis. E. coli was quantified in a Chromocult Coliform Agar (Merck, Germany) according to the manufacturer's instructions, and results were expressed in colony-forming units (CFUs). S. typhimurium was quantified in a deoxycholate-lysine-xylose agar (Merck, Germany) as described by Magri et al. [23], and results were expressed in CFUs.

\subsubsection{Cytotoxicity assay}

To evaluate the level of cytotoxicity of treated water, healthy bulbs of Allium cepa (A. cepa), acquired in the local market in Concordia, were placed to root in flasks with distilled water, at room temperature $\left( \pm 25^{\circ} \mathrm{C}\right)$, and constantly aerated, with a period of $12 \mathrm{~h}$ of light and $12 \mathrm{~h}$

\section{SN Applied Sciences}


of darkness, after which roots with about $1.0 \mathrm{~cm}$ of length were observed.

The cytotoxicity assay was performed according to Fiskesjö [13]. The reading (counting of chromosomal aberrations and micronuclei) of the slides was made with an optical microscope at $400 \times$ magnification. For each sample, three thousand cells were evaluated regarding mitotic index (MI), micronucleus and aberrations. The MI was calculated for each treatment as a ratio of dividing cells to total cells. The genetic abnormalities (anaphase bridges, laggards, micronuclei and stickiness) were scored in the abnormalities index. All tests were measured in triplicate.

\section{Results and discussion}

\subsection{Physical-chemical removal profile}

The results of turbidity and color removal are presented in Fig. 1. O. ficus-indica, C. jamacaru and C. jamacaru monstrosus were able to reduce turbidity in a range of $90-98 \%$ for all tests. Color removal efficiency ranged from 50 to $98 \%$. These results corroborate numbers previously observed by other studies $[25,38]$. Each coagulant has an ideal dose which results in greater turbidity removal and varies depending on the initial turbidity of the water [1]. Thus, the concentration of $75 \mathrm{~g} \mathrm{~L}^{-1}$ presented the highest efficiency for removal of turbidity and color (>95\%), with an exposition time of $360 \mathrm{~min}$.

Iron was removed after 30 min by all cacti species with the exception of $C$. jamacaru monstrosus when using $15 \mathrm{~g} \mathrm{~L}^{-1}$ (Fig. 2). Removal efficiency was 50\% for C. jamacaru and $100 \%$ for $O$. ficus-indica. Results corroborate Swathi et al. [36], who observed $98 \%$ iron removal rates when using $O$. ficus-indica-dried cladodes.

Sulfate removal ranged from 16 to $3\left(\mathrm{mg} \mathrm{L}^{-1}\right)$ for $O$. ficusindica, 16 to $10\left(\mathrm{mg} \mathrm{L}^{-1}\right)$ for $C$. jamacaru monstrosus and 16 to $10\left(\mathrm{mg} \mathrm{L}^{-1}\right)$ for $C$. jamacaru (Fig. 2). However, with C. jamacaru monstrosus concentrations of 25,50 and 75 $\left(\mathrm{g} \mathrm{L}^{-1}\right)$, sulfate increased after $120 \mathrm{~min}$ of exposition. With $15 \mathrm{~g} \mathrm{~L}^{-1}$ of $C$. jamacaru, there was an increase in sulfate concentration after $120 \mathrm{~min}$, which decreased shortly after. For C. jamacaru, there was an initial increase in sulfate for all concentrations and a decrease after $30 \mathrm{~min}$ of exposition (Fig. 2). Similar results ( $90 \%$ of sulfate removal) were obtained by Swathi et al. [36] with tannery wastewater using cactus powder as an adsorbent.

Figure 3 shows nitrite and nitrate removal with different bio-coagulant doses. Maximum nitrite removal was observed for C. jamacaru and C. jamacaru monstrosus, with removal rates of 66.6 and $60(\%)$, respectively, after 30-min exposition for the concentrations of 25,50 and $75\left(\mathrm{~g} \mathrm{~L}^{-1}\right)$. $O$. ficus-indica showed no removal for any exposition time; additionally, there was an increase in nitrite from 15 to 18 ( $\mathrm{mg} \mathrm{L}^{-1}$ ) (Fig. 3). Residual nitrate values below $12 \mathrm{mg} \mathrm{L}^{-1}$ were obtained when treating water with $O$. ficus-indica, $C$. jamacaru and C. jamacaru monstrosus, from an initial concentration of $24 \mathrm{mg} \mathrm{L}^{-1}$. However, bio-coagulants tested presented efficiency higher than $50 \%$ with only $30 \mathrm{~min}$ of exposition.

When observing ammonia behavior during $O$. ficusindica and C. jamacaru monstrosus exposition, an increase in ammonia levels ( 5 and $3 \mathrm{mg} \mathrm{L}^{-1}$, respectively), for all cactus concentrations (15-75 $\mathrm{g} \mathrm{L}^{-1}$ ) after $30 \mathrm{~min}$ of exposition (Fig. 3) was observed. However, contradictory results were observed using C. jamacaru, where there was no increase in ammonia concentrations. Other studies have reported that the application of natural coagulants can increase the concentration of orthophosphate, nitrogen compounds (nitrite and nitrate) and organic matter [27, 32]. This is mainly due to the functional groups present in cacti, i.e., amide, amine and amino acids [30, 35] and Opuntia mucilage, which show high concentrations of metals in their compositions [8].

The high capacity of $O$. ficus-indica to induce bio-coagulation is most likely attributed to the presence of mucilage, which is a viscous and complex substance, composed of L-arabinose, D-galactose, L-rhamnose, D-xylose and galacturonic acid as a coagulation agent [25], and is stored in the internal and external pads of the plant [33]. In the Cereus species, the concentration of this acid is lower, which explains the not so expressive coagulation when this species is used [12].

The bio-coagulation mechanisms of cacti were reported as adsorption-charge neutralization and adsorptionbridging mainly due to the anionic and macromolecular nature of deprotonated polygalacturonic acid [25, 30]. Considering all removal characteristics, studies have reported that cacti present removal rates similar to those obtained using chemical coagulants, with the advantage of generating biodegradable sludge [37].

\subsection{Pathogen reduction}

In tests using C. jamacaru, the initial amount of E. coli and S. typhimurium was $10^{5} \mathrm{CFU}$. Throughout exposition, no bacterial reduction was observed in the supernatant fraction (Fig. 4a). However, in the precipitated fraction (Fig. 4b), after $120 \mathrm{~min}$ of exposure, there was an increase of $1 \log _{10}$ of $E$. coli, but not of $S$. typhimurium.

In tests using $O$. ficus-indica, the initial amount of $E$. coli and $S$. typhimurium was $10^{3} \mathrm{CFU}$. The results showed that in the supernatant fraction there was a reduction of $90 \%$ in E. coli concentration in the first $30 \mathrm{~min}$ of exposition and $99.9 \%$ in S. typhimurium concentration after $360 \mathrm{~min}$ of exposition. These results are comparable to those found 
- Opuntia ficus indica $\quad-$ Cereus jamacaru $\quad-$ Cereus jamacaru monstrosus
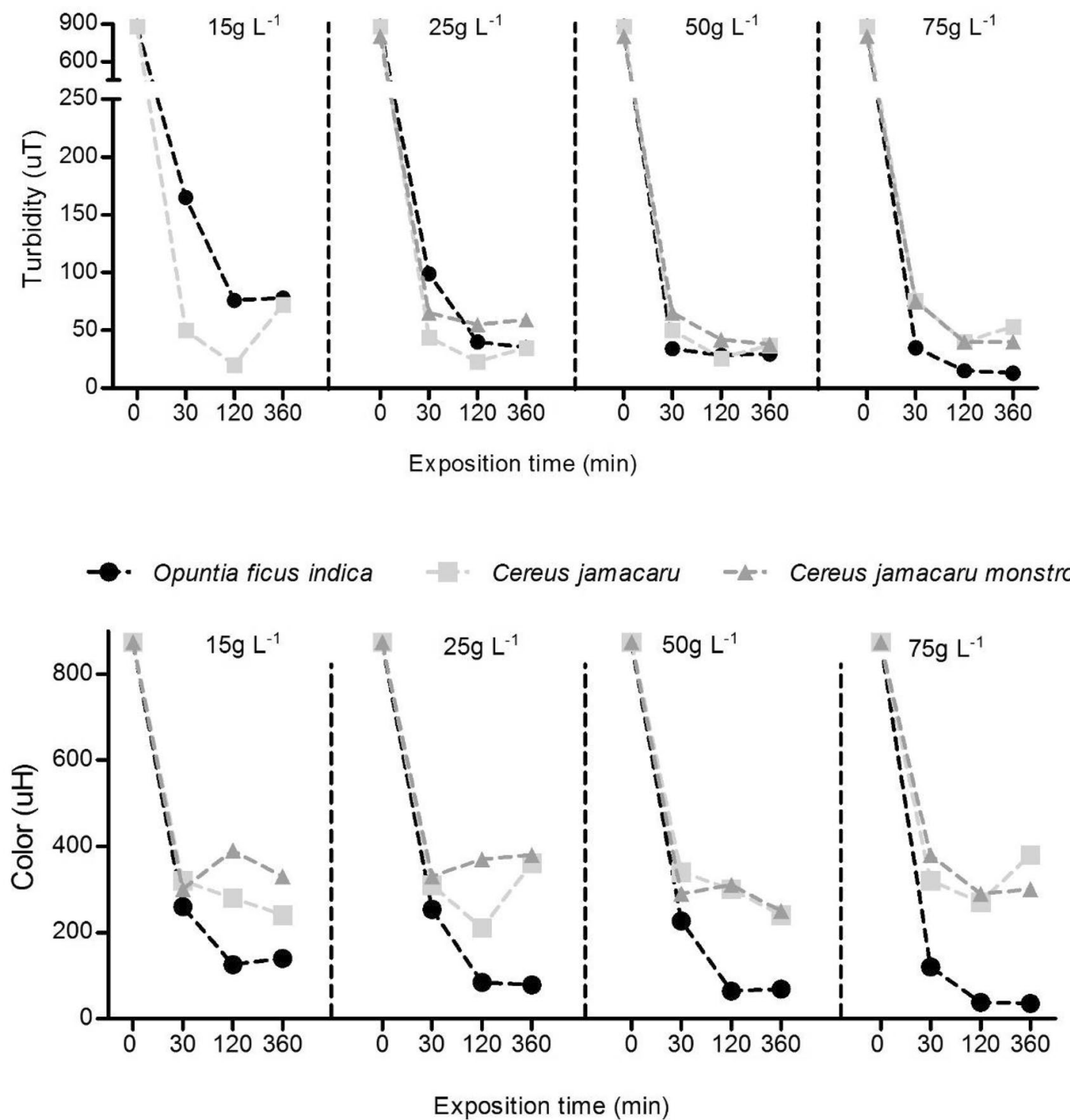

Fig. 1 Turbidity and color removal profile from water exposed to different cactus concentrations over time

with aluminum sulfate, which can achieve $90-99 \%$ of microbial removal under optimal conditions [1].

Considering the physical-chemical and nutritional characteristics of the studied cacti, $C$. jamacaru presented $325 \mathrm{~g} \mathrm{~kg}^{-1}$ of structural lignin, whereas 0 . ficus-indica presented only $122 \mathrm{~g} \mathrm{~kg}^{-1}$, which shows that the latter is a more porous and flexible material [9]. This is an important aspect to consider in the process of bioaccumulation and coagulation of bacteria by adsorption capacity. It should also be noted that bacterial growth in the presence of $C$. jamacaru may be related to the high content of sugar and proteins in its composition, which is of about $3.4 \%$ more sugar and $40 \%$ more protein when compared to O. ficusindica [9].

\subsection{Cytotoxicity residual in the water}

Mitotic index results of root meristematic cells of $A$. cepa bulbs exposed to water treated with $O$. ficus-indica, $C$. jamacaru and $C$. jamacaru monstrosus are presented in Fig. 5. Mitotic index showed a significant time-dependent response; for $O$. ficus-indica, an exposition time above $30 \mathrm{~min}$ interfered with the cell proliferation index, indicating a probable toxic effect. For C.jamacaru and C. jamacaru monstrosus, 
- Opuntia ficus indica

Cereus jamacaru - Cereus jamacaru monstrosus

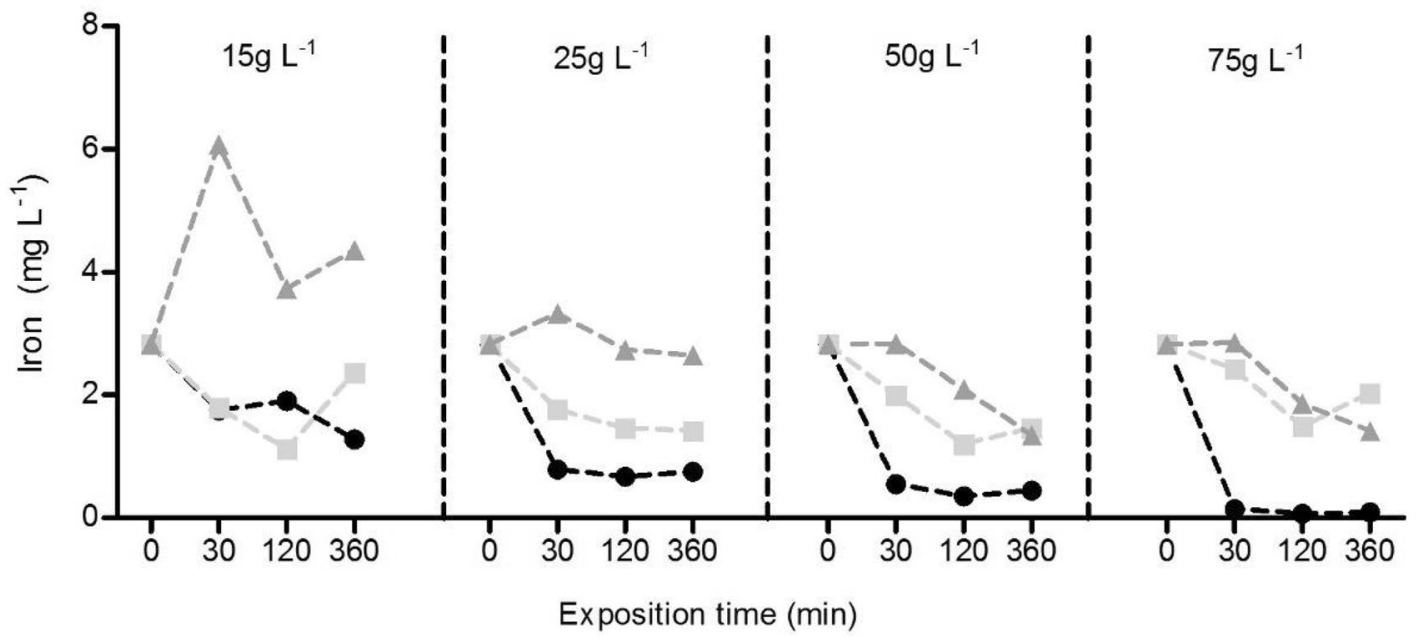

$\rightarrow$ Opuntia ficus indica $\quad-$ Cereus jamacaru $\quad-1-$ Cereus jamacaru monstrosus

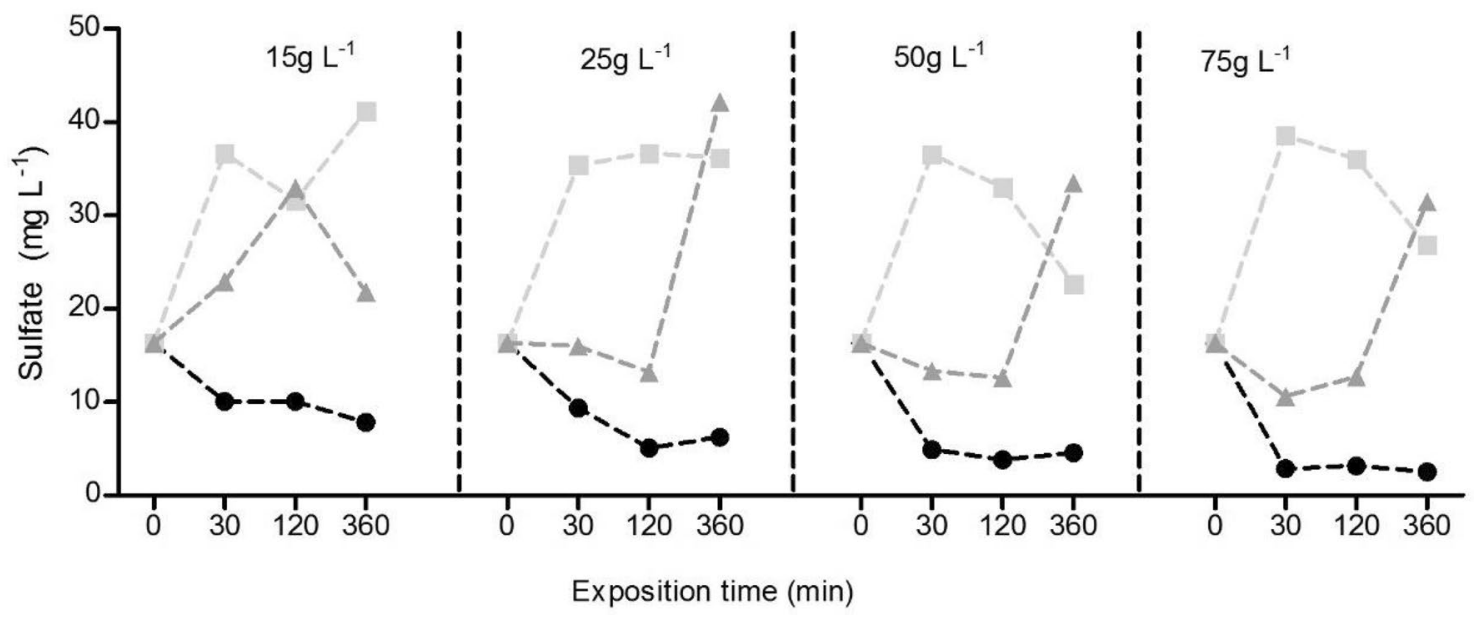

Fig. 2 Iron and sulfate removal profile from water exposed to different cactus concentrations over time

this interference was only observed after 120 min of exposition.

The toxicity of Opuntia ficus-indica has been found in other studies where it has been associated with betalain pigments [26]. For $C$. jamacaru, studies have reported toxicity effects only in concentrations smaller than $2 \mathrm{~g} \mathrm{~L}^{-1}$ [34]. This difference may be a product of the different composition of each plant, but further testing is required to confirm this.

\section{Conclusion}

- Considering the potential to reach removal rates above $70 \%$ for a larger number of pollutants (E. coli, turbidity, iron, color, nitrate), the best cactus species recommended to treat water is the $O$. ficus-indica, with a maximum exposition time of $30 \mathrm{~min}$ to avoid cytotoxicity.

- C. jamacaru and C. jamacaru monstrosus are efficient to obtain removal rates above $60 \%$ for turbidity, color and nitrate and allow a non-cytotoxic exposition time of $120 \mathrm{~min}$.

- Different dosages were tested, and the concentration with the best results was $25 \mathrm{~g} \mathrm{~L}^{-1}$.

- Considering how widespread and easy to cultivate these cacti species are, they could be recommended as a safe, low-cost alternative to other coagulation-flocculation products. 
-. Opuntia ficus indica - - Cereus jamacaru -1-. Cereus jamacaru monstrosus

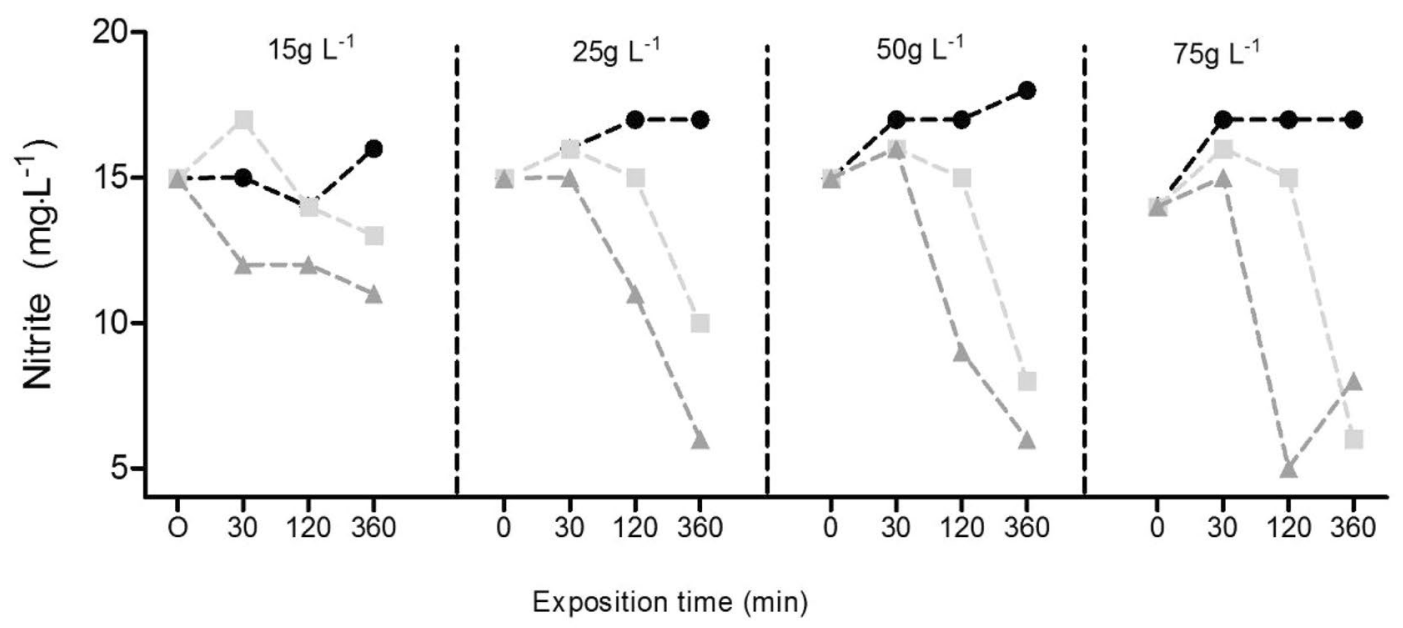

- Opuntia ficus indica - - Cereus jamacaru - Cereus jamacaru monstrosus

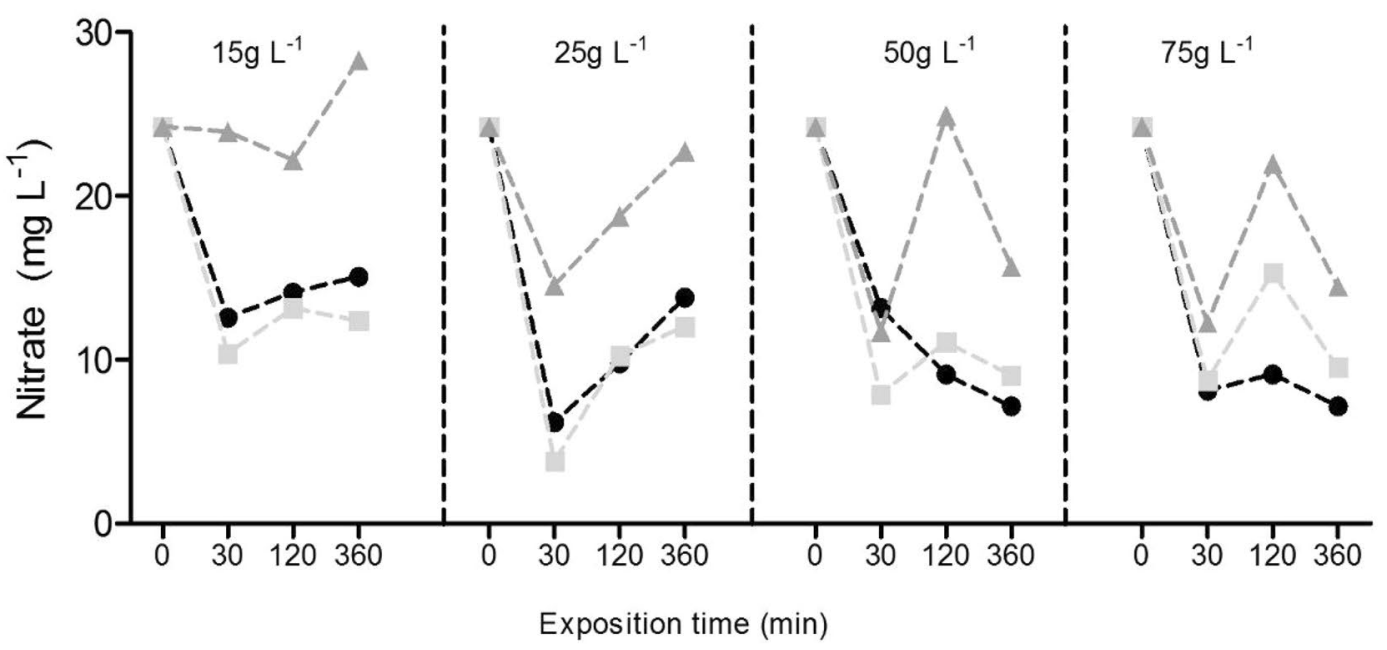

- Opuntia ficus indica ㄴ. Cereus jamacaru monstrosus

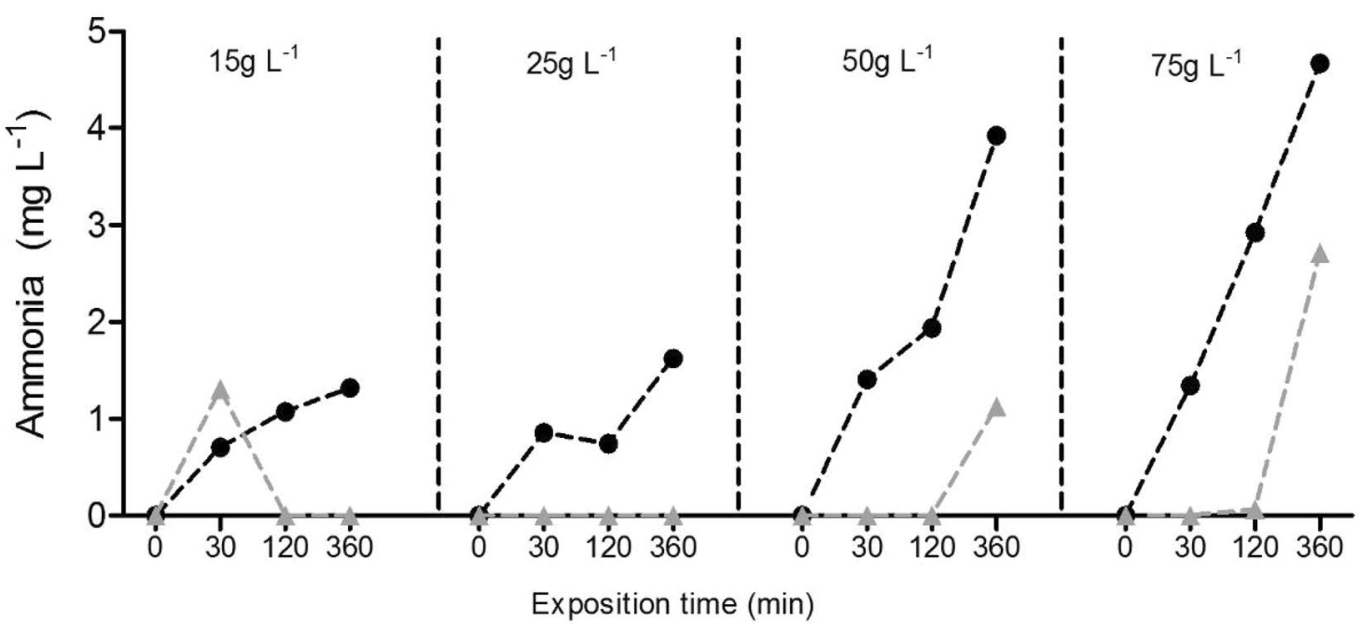

Fig. 3 Nitrite, nitrate and ammonia removal profile from water exposed to different cactus concentrations over time 


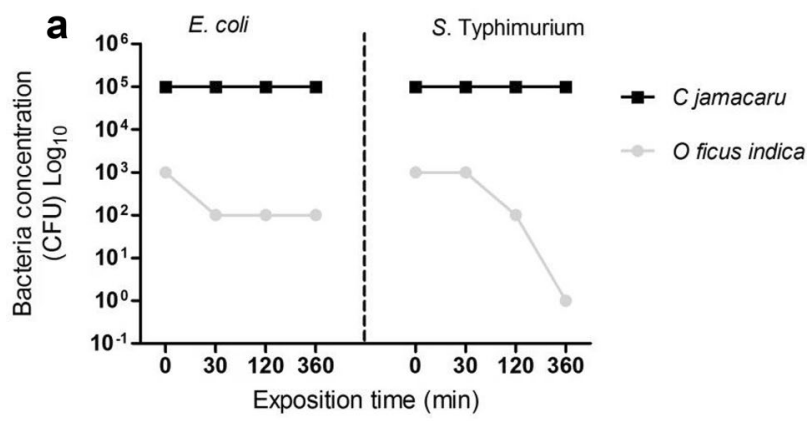

\section{Compliance with ethical standards}

Conflicts of interest The authors declare that they have no conflicts of interest.

\section{References}

1. Al-Saati NHA, Hwaidi EH, Jassam SH (2016) Comparing cactus (Opuntia spp.) and alum as coagulants for water treatment at Al-Mashroo Canal: a case study. Int J Environ Sci Technol 13(12):2875-2882

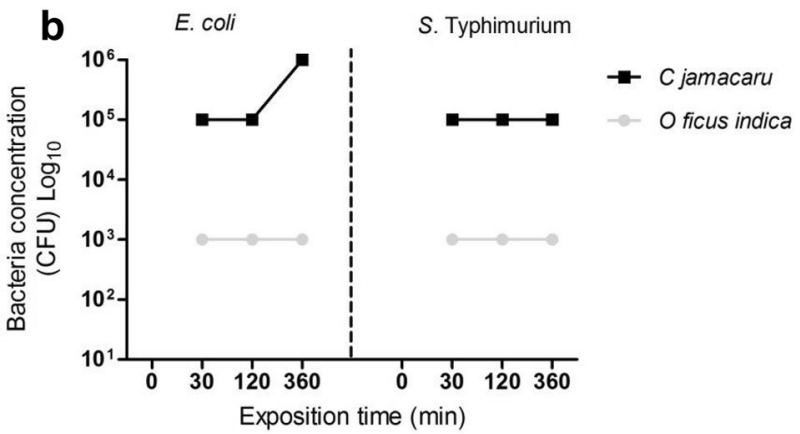

2. Andrade NADS (2018) Coagulantes de palmas forrageiras e os efeitos na turbidez e potencial hidrogeniônico em tratamento de águas. Universidade Federal da Paraíba, Graduation

3. Antov MG, Šćiban MB, Petrović NJ (2010) Proteins from common bean (Phaseolus vulgaris) seed as a natural coagulant for potential application in water turbidity removal. Biores Technol 101(7):2167-2172

4. APHA (2012) Standard methods for the examination for water and wastewater, 22nd edn. D. AmericanWaterWorks Association, Washington

5. Arvai J, Post K (2012) Risk management in a developing country context: improving decisions about point-of-use water treatment among the rural poor in africa. Risk Anal Int J 32(1):67-80

Fig. 4 Pathogen removal profile from supernatant (a) and precipitated (b) fractions exposed to different cactus concentrations over time

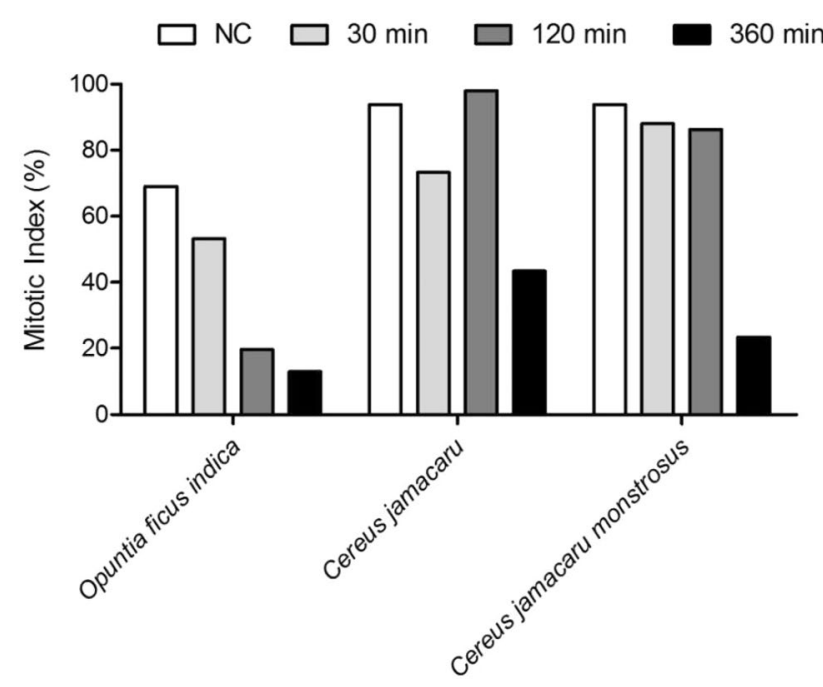

Fig. 5 Mitotic index observed in Allium cepa meristem cell exposed to water exposed to different cactus concentrations over time

6. Babu R, Chaudhuri M (2005) Home water treatment by direct filtration with natural coagulant. J Water Health 3(1):27-30

7. Becaria A, Campbell A, Bondy SC (2002) Aluminum as a toxicant. Toxicol Ind Health 18(7):309-320

8. Carpinteyro-Urban S, Torres LG (2013) Use of response surface methodology in the optimization of coagulation-flocculation of wastewaters employing biopolymers. Int J Environ Res 7(3):717-726

9. Catunda KLM, de Aguiar EM, de Góes Neto PE, da Silva JGM, Moreira JA, do Nascimento Rangel AH, de Lima Júnior DM (2016) Gross composition, fatty acid profile and sensory characteristics of Saanen goat milk fed with cacti varieties. Trop Anim Health Prod 48(6):1253-1259

10. Cesa M, Fongaro G, Barardi CRM (2016) Waterborne diseases classification and relationship with social-environmental factors in Florianópolis city-Southern Brazil. J Water Health 14(2):340-348

11. Choy SY, Prasad KMN, Wu TY, Ramanan RN (2015) A review on common vegetables and legumes as promising plant-based natural coagulants in water clarification. Int J Environ Sci Technol 12(1):367-390

12. da Silva DM, de Sousa Carvalho FR, Moura AG, Martins L, Ferreira PMT, Peron AP (2015) Cytotoxic action of the stem aqueous extract of the stem of Cereus jamacaru D.C. (mandacaru). Revista Cubana de Plantas Medicinales 20(2):226-234

13. Fiskesjö $\mathrm{G}$ (1985) The Allium test as a standard in environmental monitoring. Heraditas 102:99-112

14. Freitas TKFS, Oliveira VM, De Souza MTF, Geraldino HCL, Almeida VC, Fávaro SL, Garcia JC (2015) Optimization of coagulation-flocculation process for treatment of industrial textile wastewater using okra (A. esculentus) mucilage as natural coagulant. Ind Crops Prod 76:538-544

15. Fu F, Wang Q (2011) Removal of heavy metal ions from wastewaters: a review. J Environ Manag 92(3):407-418

16. Gamper-Rabindran S, Khan S, Timmins C (2010) The impact of piped water provision on infant mortality in Brazil: a quantile panel data approach. J Dev Econ 92(2):188-200 
17. Gensemer RW, Playle RC (1999) The bioavailability and toxicity of aluminum in aquatic environments. Crit Rev Environ Sci Technol 29(4):315-450

18. Gupta VK, Carrott PJM, Ribeiro Carrott MML, Suhas (2009) Low-cost adsorbents: growing approach to wastewater treatment-a review. Crit Rev Environ Sci Technol 39(10):783-842

19. Gupta VK et al (2012) Chemical treatment technologies for waste-water recycling-an overview. RSC Adv 2(16):6380-6388

20. Jalan J, Ravallion M (2003) Estimating the benefit incidence of an antipoverty program by propensity-score matching. J Bus Econ Stat 21(1):19-30

21. Kakoi B, Kaluli JW, Ndiba P, Thiong'o G (2016) Banana pith as a natural coagulant for polluted river water. Ecol Eng 95:699-705

22. Li X, Yang B, Feng L, Zheng H, Zeng G, Wu P (2019) Research progress of natural polymers in wastewater treatment. Mini Rev Org Chem 16(4):335-344

23. Magri ME, Philippi LS, Vinnerås B (2013) Inactivation of pathogens in feces by desiccation and urea treatment for application in urine-diverting dry toilets. Appl Environ Microbiol 79:2156-2163

24. Matilainen $A$, Vepsäläinen $M$, Sillanpää $M(2010)$ Natural organic matter removal by coagulation during drinking water treatment: a review. Adv Coll Interface Sci 159(2):189-197

25. Miller SM, Fugate EJ, Craver VO, Smith JA, Zimmerman JB (2008) Toward understanding the efficacy and mechanism of Opuntia spp. as a natural coagulant for potential application in water treatment. Environ Sci Technol 42(12):4274-4279

26. Navarro FF, Pereira FDC, Oliveira BS, Marin-Morales MA (2016) Evaluation of cytotoxic and mutagenic effects of CactiNeanutraceutical in A. cepa. Toxic Lett 259:S182

27. Ndabigengesere A, Narasiah KS (1998) Quality of water treated by coagulation using Moringa oleifera seeds. Water Res 32(3):781-791

28. Ndabigengesere A, Narasiah KS, Talbot BG (1995) Active agents and mechanism of coagulation of turbid waters using Moringa oleifera. Water Res 29(2):703-710

29. Nharingo T, Moyo M (2016) Application of Opuntia ficus-indica in bioremediation of wastewaters. A critical review. J Environ Manage 166:55-72

30. Nharingo T, Zivurawa MT, Guyo U (2015) Exploring the use of cactus Opuntia ficus indica in the biocoagulation-flocculation of $\mathrm{Pb}$ (II) ions from wastewaters. Int J Environ Sci Technol 12(12):3791-3802

31. Renault F, Sancey B, Badot PM, Crini G (2009) Chitosan for coagulation/flocculation processes-an eco-friendly approach. Eur Polym J 45(5):1337-1348

32. Rizzo $L$ (2014) The contribution of the coagulation process in controlling microbial risk and disinfection by-products formation in drinking water. In: The role of colloidal systems in environmental protection. Elsevier, pp 219-238. https://doi. org/10.1016/B978-0-444-63283-8.00009-0

33. Sáenz C, Sepúlveda E, Matsuhiro B (2004) Opuntia spp mucilage's: a functional component with industrial perspectives. J Arid Environ 57(3):275-290

34. Silva DM, Carvalho FRS, Moura AG, Martins L, Ferreira PMT, Peron AP (2015) Acción Citotoxica del extracto acuoso deel tallo de Cereus jamacaru D.C. (mandacaru). Revista Cubana de plantas medicinales 19(2):226-234

35. Singha B, Naiya TK, Kumar Bhattacharya A, Das SK (2011) Cr (VI) ions removal from aqueous solutions using natural adsorbentsFTIR studies. J Environ Prot 2(06):729

36. Swathi M, Singh AS, Aravind S, Sudhakar PK, Gobinath R, Devi DS (2014) Experimental studies on tannery wastewater using cactus powder as an adsorbent. Int J Appl Sci Eng Res 3(2):436-446

37. Vishali S, Karthikeyan R (2015) Cactus opuntia (ficus-indica): an eco-friendly alternative coagulant in the treatment of paint effluent. Desalin Water Treat 56(6):1489-1497

38. Wan J, Chakraborty T, Xu CC, Ray MB (2019) Treatment train for tailings pond water using Opuntia ficus-indica as coagulant. Sep Purif Technol 211:448-455

39. Yin CY (2010) Emerging usage of plant-based coagulants for water and wastewater treatment. Process Biochem 45(9):1437-1444

Publisher's Note Springer Nature remains neutral with regard to jurisdictional claims in published maps and institutional affiliations. 